\title{
Sistem Pedukung Keputusan Seleksi Proposal Program Penerapan Iptek Bagi Masyarakat
}

\author{
Robi Yanto ${ }^{1}$, Mohammad Guntur ${ }^{2}$ \\ ${ }^{1,2}$ Program Studi Sistem Informasi STMIK Bina Nusantara Jaya Lubuklinggau \\ Jl. Yos Sudarso, Lubuk Linggau Timur. II, Kota Lubuklinggau, Sumatera Selatan 31613 \\ e-mail: ${ }^{1}$ wrtech30@gmail.com, ${ }^{2}$ gunturmuhammad23@gmail.com
}

\begin{abstract}
Abstrak
Pengabdian masyarakat merupakan salah satu bagian terpenting bagi perguruan tinggi untuk mewujudkan peran serta pembangunan bangsa dan negara. Banyaknya kriteria penilaian yang digunakan dalam proses seleksi proposal pengabdian masyarakat menuntut unit kegiatan pengabdian masyarakat untuk lebih teliti dalam melakukan proses seleksi sesuai dengan hasil penilaian reviewer. Untuk dapat membantu proses seleksi proposal pengabdian masyarakat dibutuhkan sistem pendukung keputusan yang dapat membantu proses penilaian yang lebih tepat dan objektif. Adapun tujuan penelitian ini adalah membangun Sistem pendukung keputusan menggunakan metode Simple Multi Attribute Rating Technique, dimana metode ini digunakan sebagai media bantu penentuan kriteria pemilihan berdasarkan bobot dari kriteria dan subkriteria untuk proses perangkingan terhadap alternatif. Dari analisa metode dan sistem dihasilkan penilaian terhadap proposal pengabdian masyarakat Tahun 2017 dengan rekomendasi sangat layak yaitu $A_{1}$ dengan hasil perangkingan 83,75, $A_{4}=88$, rekomendasi Layak yaitu $A_{2}$ dengan hasil perangkingan 60,75 dan $A_{5}=63,25$ dan rekomendasi tidak layak adalah $A_{3}$ dengan hasil perangkingan 33.
\end{abstract}

Kata kunci: Pengabdian Masyarakat, PPIM, Sistem Pendukung Keputusan, Smart

\begin{abstract}
Community service is one of the most important parts for universities to realize the role of the nation and state development. A large number of assessment criteria used in the community service proposal selection process requires the community service unit to be more thorough in carrying out the selection process in accordance with the results of the reviewer assessment. To be able to help the community service proposal selection process, a decision support system is needed that can help a more precise and objective assessment process. The purpose of this study is to build a decision support system using the Simple Multi-Attribute Rating Technique method, where this method is used as an auxiliary media to determine selection criteria based on the weight of the criteria and sub-criteria for the ranking process against alternatives. From the analysis of methods and systems results in an assessment of 2017 community service proposals with recommendations that are very feasible namely Al with a ranking of 83.75, $A 4=88$, Worthy recommendation is $A 2$ with ranking results of 60.75 and $A 5$ $=63.25$ and recommendations are not feasible is $A 3$ with a ranking of 33 .
\end{abstract}

Keywords: Community Service, PPIM, Decision Support System, Smart.

\section{Pendahuluan}

Skema Pengabdian kepada Masyarakat yang ditawarkan pemerintah melalui program hibah pengabdian kepada masyarakat oleh direktorat Jendral Riset dan Pendidikan tinggi merupakan salah satu peran pemerintah untuk meningkatkan kompetensi dosen dalam melaksanakan tri dharma perguruan tinggi. Dalam upaya peningkatan peran serta dosen terhadap kebutuhan masyarakat tentunya STMIK Bina Nusantara Jaya Memiliki rencana 
strategis bidang pengabdian masyarakat yaitu dengan adannya pendampingan bagi dosen untuk berperan serta dalam perolehan dana hibah pengabdian masyarakat khusunya pada program penerapan iptek bagi masyarakat. Adapun selama ini proses seleksi yang dilaksanakan melalui unit penelitian dan pengabdian masyarakat sesuai dengan prosedur yang ada yaitu dengan melakukan proses pengusulan proposal pengabdian masyarakat, kemudian dinilai oleh tim penilai berdasarkan lembar penilaian dengan kriteria yang telah ditentukan. Namun kegiatan tersebut belum didukung dengan sistem informasi sehingga proses seleksi proposal pengabdian masyarakat harus dilakukan dengan rekapitulasi data penilaian yang membutuhkan waktu penilaian yang cukup lama. Selain itu proses penilaian yang dilakukan belum menggunakan metode yang relevan sehingga hasil penilaian seleksi proposal pengabdian masyarakat belum obyektif karena hasil penilaian proposal yang diperoleh oleh dosen pengusul merupakan hasil akhir dalam bentuk rekomendasi kelayakan yang tertuang dalam surat keputusan, sehingga perlunya penerapan sistem pendukung keputusan dengan kriteria yang sesuai dengan kebutuhan seleksi proposal pengabdian masyarakat seperti ketajaman analisis, rumusan masalah, kesesuaian kompetensi tim, metode pelaksanaan, kesesuaian penugasan tim, kualitas Iptek, kualitas luaran, target, jadwal, RAB, dan kontribusi mitra[1]

Sistem pendukung keputusan seleksi proposal program penerapan iptek bagi masyarakat merupakan salah satu solusi dalam membantu proses seleksi proposal pengabdian masyarakat yang akan diikutsertakan dalam seleksi hibah pengabdian masyarakat melalui pendanaan dikti. Adapun sistem pendukung keputusan dibangun untuk membantu unit penelitian dan pengabdian masyarakat untuk mengetahui proposal yang akan diikutsertakan proses seleksi oleh dikti. Sistem pendukung keputusan adalah teknik dalam pengambilan keputusan secara semi terstruktur dan tidak terstruktur yang dilakukan oleh level pimpinan melalui penerapan data dan model yang tersedia[2][3][4].

Dalam membangun sistem pendukung keputusan seleksi proposal program penerapan iptek bagi masyarakat digunakan metode simple multi attribut rating technique. SMART merupakan metode pengambilan keputusan yang fleksibel karna metode SMART digunakan sebagai kesederhanaan dalam merepson kebutuhan pengambil keputusan dan cara menganalisa respon[5]. Metode SMART juga merupakan teknik pengambilan keputusan multi atribut yang digunakan untuk mendukung pembuat keputusan dalam memilih beberapa alternatif[6].

Dari hasil penelitian terdahulu metode SMART dapat menyelesaikan masalah seleksi pemerima bantuan $\mathrm{PkH}$ menggunakan 14 kriteria. Banyaknya kriteria yang digunakan sangat mempengaruhi kualitas dari hasil yang diinginkan[5]

Metode SMART juga dapat digunakan untuk mendukung keputusan pemilihan gedung serbaguna di Kota Bengkulu berbasis anroid[6]. Selain itu Metode SMART juga dapat membantu pengambilan keputusan sistem penilaian kinerja dosen teladan[7]. Dilihat dari hasil analisa permasalahan dan penelitian sebelumnya, maka tujuan penelitian ini adalah membangun sistem pendukung keptusan dengan menggunakan metode SMART untuk proses seleksi proposal program penerapan iptek bagi masyarakat.

\section{Metode Penelitian}

\subsection{Tahapan Penelitian}

Metode yang digunakan pada penelitian ini adalah metode Simple Multi Attribute Rating Technique karena metode ini menerapkan proses penilaian banyak kriteria untuk menghasilkan perangkingan terhadap penilaian terbaik sesuai dengan nilai rekomendasi. Tahapan penelitian untuk seleksi proposal pengabdian kepada masyarakat seperti pada Gambar 1.

Analisa Permasalahan

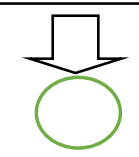




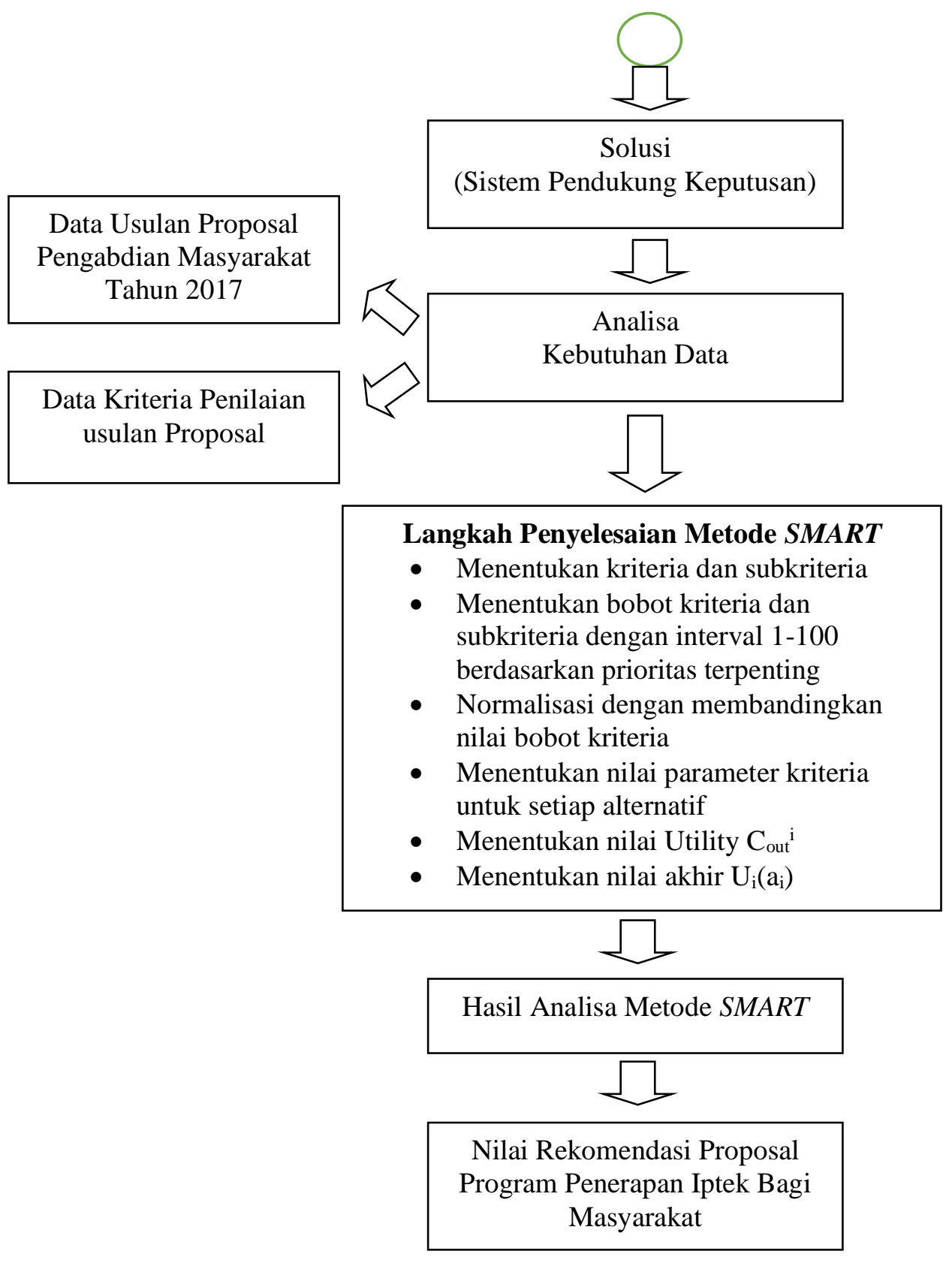

Gambar 1. Tahapan Penelitian

Dari tahapan penelitian pada gambar 1 menjelaskan langkah yang dilakukan dalam penelitian tentang proses seleksi proposal pengabdian masyarakat yaitu (a) melakukan analisa terhadap permasalahan yang terjadi dalam proses seleksi proposal pengabdian masyarakat untuk mengidentifikasi masalah yang akan dijadikan dasar sebagai pencarian solusi, (b) solusi membangun sistem pendukung keputusan dari permasalahan yang telah diidentifikasi, (c) melakukan proses analisa data yang dibutuhkan dalam menerapkan solusi yang ditawarkan diantaranya analisa terhadap data proposal sebagai alternatif dan analisa persyaratan proposal sebagai kriteria seleksi, (d) selanjutnya dilakukan proses analisa dengan metode yang dipilih yaitu menggunakan metode SMART untuk dapat melakukan proses perangkingan, (e) hasil analisa dengan metode merupakan hasil perangkingan terhadap proposal pengabdian masyarakat yang diusulkan oleh dosen, (f) tahapan akhir adalah rekomendasi hasil yang diperoleh dari analisa dengan metode dan sistem yang dibangun sebagai hasil seleksi proposal yang dapat digunakan oleh pihak pengambil keputusan. 


\subsection{Sistem Pendukung Keputusan}

Sistem penunjang keputusan adalah pendekatan secara logis, yang dimulai dengan permasalahan pengambil keputusan, fakta-fakta, menetapkan sejumlah kriteria keputusan untuk memilih alternatif-alternatif tindakan yang paling tepat sebagai solusi keputusan[8]. Terdapat dua teknik pengambilan keputusan pertama sistem tertutup yaitu pengambilan keputusan tanpa dipengaruhi oleh lingkungan diluar sistem dan kedua sistem terbuka dimana lingkungan diluar sistem sangat mempengaruhi dalam pengambilan keputusan[9].

\subsection{Metode Simple Multi Attribute Rating Technique(SMART)}

Metode pengambilan keputusan terhadap banyak kriteria dikembangkan oleh Edward pada tahun 1997. Metode pengambilan keputusan melalui banyak kriteria didasarkan pada teori bahwa alternatif terdiri dari beberapa kriteria yang mempunyai nilai dan setiap bobot kriteria menggambarkan tingakat kepentingan dengan kriteria lainnya. Bobot digunakan setiap alternatif untuk penilaian agar diperoleh alternatif terbaik.[10] adapun langkah-langkah pada metode smart sebagai berikut :

Pada penelitian ini metode yang digunakan adalah metode Simple Multi Attribute Rating Technique (SMART) dengan tahapan sebagai berikut[11].

a. Penentuan kriteria yang akan diterapkan.

b. Menentukan bobot kriteria dengan range 1-100 untuk setiap kriteria berdasarkan prioritas.

c. Melakukan normalisasi kriteria melalui perbandingan nilai bobot kriteria terhadap jumlah bobot kriteria pada suatu skala untuk semua rating alternatif yang tersedia. Dengan persamaan :

$$
\text { Normalisasi }=\frac{w_{j}}{\sum w_{j}}
$$

Dimana Wj merupakan nilai bobot kriteria, sedangkan $\sum \mathrm{Wj}$ merupakan total jumlah bobot kriteria.

d. Menentukan parameter dari kriteria untuk setiap alternatif.

e. Menentukan nilai utility dengan proses konversi pada masing-masing kriteria menjadi nilai kriteria yang baku. Nilai utility menggunakan persamaan :

$$
u_{i}\left(a_{i}\right)=100 \frac{c_{\max }-C_{\text {mui }}}{c_{\max }-C_{\min }} \%
$$

Dimana $u_{i}\left(a_{i}\right)$ adalah nilai utility kriteria ke-1 untuk kriteria ke - I, C_max adalah nilai kriteria maksimal, $C_{\text {min }}$ adalah nilai kriteria minimal dan $C_{\text {out }}{ }^{i}$ adalah nilai kriteria ke- i. Maka didapat nilai tersebut adalah :

$$
C_{\text {out }}{ }^{i}=u_{i}\left(a_{i}\right), 1=0 ; 2=0,5: 3=1
$$

f. Menentukan nilai akhir dari masing-masing kriteria dengan perkalian nilai yang didapat dari normalisasi nilai kriteria data baku dengan nilai normalisasi bobot kriteria. Lalu ditotalkan semua hasil perkalian yang diperoleh.

$$
u_{i}\left(a_{i}\right)=\sum_{j=i}^{m} w_{j} u_{i}\left(a_{i}\right)
$$

Dimana $\boldsymbol{u}_{i}\left(\boldsymbol{a}_{i}\right)$ adalah nilai alternative $\boldsymbol{w}_{\boldsymbol{j}}$ adalah hasil dari bobot normalisasi kriteria dan $\boldsymbol{u}_{i}\left(\boldsymbol{a}_{i}\right)$ adalah hasil penentuan utility.

\section{Hasil dan Pembahasan}

\subsection{Menentukan Kriteria dan Alternatif}

Pemilihan data alternatif merupakan data usulan proposal pengabdian masyarakat dengan skema Iptek bagi Masyarakat (IbM) Tahun 2017 STMIK Bina Nusantara Jaya Lubuklinggau. 
terdiri dari lima proposal IbM seperti pada tabel 1. Kriteria yang diterapkan untuk penilaian seleksi proposal program penerapan iptek bagi masyarakat berdasarkan kriteria penilaian usulan dikti seperti pada tabel 2.

Tabel 1. Data Alternatif

\begin{tabular}{|c|l|c|}
\hline No & \multicolumn{1}{|c|}{ Alternatif } & Keterangan \\
\hline $\mathbf{1}$ & $\begin{array}{l}\text { IbM Pemanfaatan E-Learning untuk meningkatkan } \\
\text { Kompetensi TIK Bagi Guru dan Siswa SMK Kabupaten } \\
\text { Musi Rawas }\end{array}$ & $\mathrm{A}_{1}$ \\
\hline $\mathbf{2}$ & $\begin{array}{l}\text { IbM Kelompok Guru Sekolah Lanjutan Tingkat Pertama } \\
\text { Kecamatan Tugumulyo Dalam Menyusun Bahan Ajar } \\
\text { Berbasis Multi Media }\end{array}$ & $\mathrm{A}_{2}$ \\
\hline $\mathbf{3}$ & $\begin{array}{l}\text { Pelatihan HTML sebagai Bekal Technopreneurship Bagi } \\
\text { Alumni SMK Tugumulyo Kabupaten Musi Rawas }\end{array}$ & $\mathrm{A}_{3}$ \\
\hline $\mathbf{4}$ & $\begin{array}{l}\text { IbM Pelatihan Pengelolaan Website dalam upaya } \\
\text { peningkatan promosi produk UMKM Keluarahan Tanah } \\
\text { Periuk Kota Lubuklinggau }\end{array}$ & $\mathrm{A}_{4}$ \\
\hline $\mathbf{5}$ & $\begin{array}{l}\text { IbM Pengembangan E-Learning Untuk Meningkatkan } \\
\text { Kompetensi Pedagogik Guru Smk Negeri Rawas Ulu }\end{array}$ & $\mathrm{A}_{5}$ \\
\hline
\end{tabular}

Data alternatif pada tabel 1 merupakan data usulan proposal pengabdian masyarakat yang diusulkan oleh dosen STMIK Bina Nusantara Jaya tahun 2017. Dari alternatif tersebut di konversikan dalam bentuk simbol $\mathrm{A}_{1}-\mathrm{A}_{\mathrm{n}}$ untuk penerapan dalam penggunaan persamaan pada metode SMART.

Tabel 2. Data Bobot Kriteria dan Normalisasi Bobot

\begin{tabular}{|c|l|c|c|}
\hline No & \multicolumn{1}{|c|}{ Kriteria } & Bobot & $\begin{array}{c}\text { Normalisasi } \\
\text { Bobot }\end{array}$ \\
\hline $\mathbf{1}$ & \multicolumn{1}{|c|}{ Ketajaman analisis situasi permasalahan mitra $\left(\mathrm{C}_{1}\right)$} & $10 \%$ & 0.1 \\
\hline $\mathbf{2}$ & Rumusan masalah prioritas mitra $\left(\mathrm{C}_{2}\right)$ & $10 \%$ & 0.1 \\
\hline $\mathbf{3}$ & $\begin{array}{l}\text { Kesesuaian kompentensi tim untuk menyelesaikan } \\
\text { permasalah mitra }\left(\mathrm{C}_{3}\right)\end{array}$ & $5 \%$ & 0.05 \\
\hline $\mathbf{4}$ & $\begin{array}{l}\text { Metode pelaksanaan, solusi, dan rencana kegiatan yang } \\
\text { ditawarkan }\left(\mathrm{C}_{4}\right)\end{array}$ & $15 \%$ & 0.15 \\
\hline $\mathbf{5}$ & Kesesuaian penugasan tim pelaksana $\left(\mathrm{C}_{5}\right)$ & $5 \%$ & 0.05 \\
\hline $\mathbf{6}$ & Kualitas Iptek yang ditawarkan (hasil penelitian) $\left(\mathrm{C}_{6}\right)$ & $15 \%$ & 0.15 \\
\hline $\mathbf{7}$ & Kualitas luaran wajib yang dijanjikan $\left(\mathrm{C}_{7}\right)$ & $10 \%$ & 0.1 \\
\hline $\mathbf{8}$ & Kewajaran tahapan target capaian luaran wajib $\left(\mathrm{C}_{8}\right)$ & $5 \%$ & 0.05 \\
\hline $\mathbf{9}$ & Kesesuaian jadwal $\left(\mathrm{C}_{9}\right)$ & $5 \%$ & 0.05 \\
\hline $\mathbf{1 0}$ & Kewajaran RAB usulan $\left(\mathrm{C}_{10}\right)$ & $5 \%$ & 0.05 \\
\hline $\mathbf{1 1}$ & Kontribusi partisipasi mitra $\left(\mathrm{C}_{11}\right)$ & $5 \%$ & 0.05 \\
\hline
\end{tabular}

Data kriteria pada tabel 2 adalah data yang diperoleh dari buku pedoman pelaksanaan penelitian dan pengabdian masyarakat edisi XII, dimana kriteria yang digunakan adalah 11 kriteria seleksi usulan proposal hibah dikti tahun 2018.

\subsection{Menentukan Nilai Utility untuk Setiap Alternatif}

Tahap perhitungan menentukan nilai utility menggunakan persamaan rumus ke- 2 . Untuk melakukan proses masukan nilai pada kriteria dilakukan proses penentuan nilai utility pada setiap kriteria dapat dilihat pada tabel 3. 
Tabel 3. Nilai Utility

\begin{tabular}{|c|c|c|c|}
\hline No & Kriteria & Subkriteria & Input $\mathrm{C}_{\text {oun }}{ }^{\mathrm{i}}$ \\
\hline 1 & $\mathbf{C}_{1}$ & $\begin{array}{l}\text { Sangat Baik } \\
\text { Baik } \\
\text { Cukup } \\
\text { Rendah }\end{array}$ & $\begin{array}{c}1 \\
3.2 \\
5.5 \\
7.75\end{array}$ \\
\hline 2 & $\mathrm{C}_{2}$ & $\begin{array}{l}\text { Sangat tepat } \\
\text { Tepat } \\
\text { Cukup tepat } \\
\text { Tidak Tepat }\end{array}$ & $\begin{array}{c}1 \\
3.2 \\
5.5 \\
7.75\end{array}$ \\
\hline 3 & $\mathrm{C}_{3}$ & $\begin{array}{l}\text { Kompeten } \\
\text { Tidak kompeten }\end{array}$ & $\begin{array}{c}1 \\
5.5\end{array}$ \\
\hline 4 & $\mathrm{C}_{4}$ & $\begin{array}{l}\text { Terukur } \\
\text { Cukup Terukur } \\
\text { Tidak Terukur }\end{array}$ & $\begin{array}{c}1 \\
4.6 \\
7.75\end{array}$ \\
\hline 5 & $\mathrm{C}_{5}$ & $\begin{array}{l}\text { Sesuai } \\
\text { Tidak Sesuai }\end{array}$ & $\begin{array}{c}1 \\
5.5\end{array}$ \\
\hline 6 & $\mathrm{C}_{6}$ & $\begin{array}{l}\text { Sangat Baik } \\
\text { Baik } \\
\text { Cukup } \\
\text { Rendah }\end{array}$ & $\begin{array}{c}1 \\
3.2 \\
5.5 \\
7.75\end{array}$ \\
\hline 7 & $\mathrm{C}_{7}$ & $\begin{array}{l}\text { Berkualitas } \\
\text { Cukup berkualitas } \\
\text { Tidak berkualitas }\end{array}$ & $\begin{array}{c}1 \\
4.6 \\
7.75\end{array}$ \\
\hline 8 & $\mathrm{C}_{8}$ & $\begin{array}{l}\text { Wajar } \\
\text { Cukup wajar } \\
\text { Tidak wajar }\end{array}$ & $\begin{array}{c}1 \\
4.6 \\
7.75\end{array}$ \\
\hline 9 & $\mathrm{C}_{9}$ & $\begin{array}{l}\text { Sesuai } \\
\text { Cukup sesuai } \\
\text { Tidak Sesuai }\end{array}$ & $\begin{array}{c}1 \\
4.6 \\
7.75\end{array}$ \\
\hline 10 & $\mathrm{C}_{10}$ & $\begin{array}{l}\text { Wajar } \\
\text { Cukup wajar } \\
\text { Tidak wajar }\end{array}$ & $\begin{array}{c}1 \\
4.6 \\
7.75\end{array}$ \\
\hline 11 & $\mathrm{C}_{11}$ & $\begin{array}{l}\text { Sangat berkontribusi } \\
\text { Cukup berkontribusi } \\
\text { Tidak berkontribusi }\end{array}$ & $\begin{array}{c}1 \\
4.6 \\
7.75\end{array}$ \\
\hline
\end{tabular}

Pada tabel 3. Nilai input $\mathrm{C}_{\text {oun }} \mathrm{i}$ diperoleh berdasarkan persamaan ke 2 dan dilihat dari tingkat kepentingan dari kriteria yang digunakan.

\subsection{Hasil Nilai Utility}

Dilakukan penentuan nilai Cmax dan Cmin. Adapun nilai Cmax dan Cmin dapat diketahui melalui nilai input $\mathrm{C}_{\text {out }}{ }^{\mathrm{i}}$ yaitu nilai maksimal 10 dan minimal 1 . Hasil nilai utility diperoleh dengan persamaan ke-2 sebagai berikut :

1. Kriteria ketajaman analisis situasi permasalahan mitra $\left(\mathrm{C}_{1}\right)$

$$
\begin{aligned}
& \text { subkriteria sangat baik }=100 \frac{10-1}{10-1} \%=100 \\
& \text { subkriteria baik }=100 \frac{10-3.2}{10-1} \%=75 \\
& \text { subkriteria Cukup }=100 \frac{10-5.5}{10-1} \%=50 \\
& \text { subkriteria Rendah }=100 \frac{10-7.75}{10-1} \%=25
\end{aligned}
$$


2. Kriteria Rumusan masalah prioritas mitra $(\mathrm{C} 2)$

$$
\begin{aligned}
& \text { subkriteria sangat tepat }=100 \frac{10-1}{10-1} \%=100 \\
& \text { subkriteria tepat }=100 \frac{10-3.2}{10-1} \%=75 \\
& \text { subkriteria cukup tepat }=100 \frac{10-5.5}{10-1} \%=50 \\
& \text { subkriteria Tidak Tepat }=100 \frac{10-7.75}{10-1} \%=25
\end{aligned}
$$

3. Kriteria Kesesuaian kompentensi tim untuk menyelesaikan permasalah mitra $\left(\mathrm{C}_{3}\right)$

subkriteria Kompeten $=100 \frac{10-1}{10-1} \%=100$

subkriteria Tidak Kompeten $=100 \frac{10-5.5}{10-1} \%=50$

4. Kriteria Metode pelaksanaan, solusi, dan rencana kegiatan yang ditawarkan $\left(\mathrm{C}_{4}\right)$

$$
\begin{aligned}
& \text { subkriteria Terukur }=100 \frac{10-1}{10-1} \%=100 \\
& \text { subkriteria cukup terukur }=100 \frac{10-4.6}{10-1} \%=60 \\
& \text { subkriteria Tidak terukur }=100 \frac{10-7.75}{10-1} \%=25
\end{aligned}
$$

5. Kriteria Kesesuaian penugasan tim pelaksana (C5)

$$
\begin{aligned}
& \text { subkriteria Sesuai }=100 \frac{10-1}{10-1} \%=100 \\
& \text { subkriteria Tidak sesuai }=100 \frac{10-5.5}{10-1} \%=50
\end{aligned}
$$

6.

yang ditawarkan (hasil penelitian) $\left(\mathrm{C}_{6}\right)$

$$
\begin{aligned}
& \text { subkriteria Sangat baik }=100 \frac{10-1}{10-1} \%=100 \\
& \text { subkriteria baik }=100 \frac{10-3.2}{10-1} \%=75 \\
& \text { subkriteria cukup }=100 \frac{10-5.5}{10-1} \%=50 \\
& \text { subkriteria Rendah }=100 \frac{10-7.75}{10-1} \%=25
\end{aligned}
$$

7.

wajib yang dijanjikan (C7)

Kriteria Kualitas luaran

$$
\begin{aligned}
& \text { subkriteria Sangat berkualitas }=100 \frac{10-1}{10-1} \%=100 \\
& \text { subkriteria cukup berkualitas }=100 \frac{10-4.6}{10-1} \%=60 \\
& \text { subkriteria Kurang berkualitas }=100 \frac{10-7.75}{10-1} \%=25
\end{aligned}
$$

8.

tahapan target capaian luaran wajib (C8)

$$
\begin{aligned}
& \text { subkriteria Wajar }=100 \frac{10-1}{10-1} \%=100 \\
& \text { subkriteria Cukup Wajar }=100 \frac{10-4.6}{10-\frac{1}{1}} \%=60 \\
& \text { subkriteria Tidak wajar }=100 \frac{10-7.75}{10-1} \%=25
\end{aligned}
$$


9.

jadwal (C9)

subkriteria Sesuai $=100 \frac{10-1}{10-1} \%=100$

subkriteria Cukup sesuai $=100 \frac{10-4.6}{10-1} \%=60$

subkriteria Tidak Sesuai $=100 \frac{10-7.75}{10-1} \%=25$

10.

usulan (C10)

subkriteria Wajar $=100 \frac{10-1}{10-1} \%=100$

subkriteria cukup wajar $=100 \frac{10-4.6}{10-1} \%=60$

subkriteria Tidak wajar $=100 \frac{10-7.75}{10-1} \%=25$ 11.

partisipasi mitra $(\mathrm{C} 11)$

subkriteria Sangat berkontribusi $=100 \frac{10-1}{10-1} \%=100$

subkriteria cukup berkontribusi $=100 \frac{10-4,6}{10-1} \%=60$

subkriteria Kurang berkontribusi $=100 \frac{10-7.75}{10-1} \%=25$

Penetapan nilai rekomendasi untuk hasil yang diperoleh dari perhitungan menggunakan metode SMART seperti pada tabel 4, dimana range nilai rekomendasi diperoleh berdasarkan Pedoman Pelaksanaan Pengabdian Kepada Masyarakat Tahun STMIK BNJ 2017.

Tabel 4. Nilai Rekomendasi

\begin{tabular}{|c|c|c|}
\hline No & Nilai Akhir & Rekomendasi \\
\hline 1 & 0 Sampai 49 & Tidak Layak \\
\hline 2 & 50 Sampai 69 & Dipertimbangkan \\
\hline 3 & 70 Sampai 79 & Layak \\
\hline 4 & 80 Sampai 100 & Sangat Layak \\
\hline
\end{tabular}

Pada tabel 4 nilai rekomendasi digunakan oleh pengambil keputusan sebagai penilaian terhadap hasil seleksi proposal pengabdian masyarakat dimana jika nilai akhir $>=80$ maka rekomendasi sangat layak, jika nilai akhir $>=70$ maka rekomendasi Layak, jika nilai akhir $>=50$ maka rekomendasi dipertimbangkan dan jika <=49 maka rekomendasi tidak layak.

\subsection{Hasil Perhitungan}

perhitungan menggunakan metode SMART berdasarkan data usulan proposal pengabdian masyarakat, untuk perhitungan nilai rekomendasi yaitu nilai utlility yang telah diperoleh dikali dengan bobot kriteria yang telah ditentukan sehingga masing masing kriteria memperoleh nilai akhir yang ditotalkan dari semua nilai kriteria.

Tabel 5. Hasil Perhitungan

\begin{tabular}{|c|c|c|c|c|c|c|c|c|c|c|c|c|c|c|}
\hline No & $\begin{array}{l}\text { Alternatif } \\
\text { /Kriteria }\end{array}$ & $\mathrm{C}_{1}$ & $\mathrm{C}_{2}$ & $\mathrm{C}_{3}$ & $\mathrm{C}_{4}$ & $\mathrm{C}_{4}$ & $\mathrm{C}_{6}$ & $\mathbf{C}_{7}$ & $\mathrm{C}_{8}$ & $\mathrm{C}_{9}$ & $\mathrm{C}_{10}$ & $C_{11}$ & Hasil & Ket \\
\hline- & Bobot & 0,1 & 0,1 & 0,05 & 0,15 & 0,05 & 0,15 & 0,1 & 0,05 & 0,05 & 0,05 & 0,05 & - & - \\
\hline 1 & $\mathbf{A}_{1}$ & 100 & 100 & 50 & 100 & 100 & 100 & 100 & 100 & 100 & 100 & 25 & 83,75 & Sangat Layak \\
\hline 2 & $\mathbf{A}_{2}$ & 75 & 75 & 100 & 60 & 50 & 75 & 60 & 60 & 60 & 60 & 60 & 60,75 & Dipertimbangkan \\
\hline 3 & $\mathbf{A}_{3}$ & 25 & 50 & 50 & 25 & 50 & 50 & 25 & 25 & 25 & 60 & 25 & 33 & Tidak Layak \\
\hline 4 & $\mathbf{A}_{4}$ & 100 & 100 & 100 & 100 & 100 & 100 & 100 & 60 & 100 & 100 & 100 & 88 & Sangat Layak \\
\hline 5 & A5 & 75 & 75 & 100 & 60 & 100 & 75 & 60 & 60 & 60 & 60 & 60 & 63,25 & Dipertimbang \\
\hline
\end{tabular}


Hasil perhitungan seperti pada tabel 5 dengan persamaan ke-3 dan 4 digunakan sebagai nilai rekomendasi terhadap alternatif yang akan dipilih sesuai dengan range rekomendasi nilai.

Dari lima (5) alternatif yang dianalisa dengan metode SMART diperoleh hasil rekomendasi penilaian usulan proposal pengabdian masyarakat sesuai dengan bobot penilaian pada setiap kriteria. Nilai rekomendasi dari alternatif $\mathrm{A}_{1}$ dan $\mathrm{A}_{4}$ dengan hasil perangkingan 83,75 dan 88 direkomendasikan sangat layak, sedangkan untuk $\mathrm{A}_{2}$ dan $\mathrm{A}_{5}$ dengan hasil perangkingan 60,75 dan 63,25 direkomendasikan untuk dipertimbangkan dan untuk $\mathrm{A}_{3}$ dengan hasil perangkingan 33 direkomendasikan tidak layak.

Tahap selanjutnya, dilakukan pembuatan sistem menggunakan model perancangan Data Flow Diagram (DFD) dan pada tahap perancangan basis data menggunakan Model keterhubungan antar entitas, pemrograman PHP sebagai alat bantu dalam pengambilan keputusan seleksi proposal pengabdian kepada masyarakat seperti gambar $2-6$.

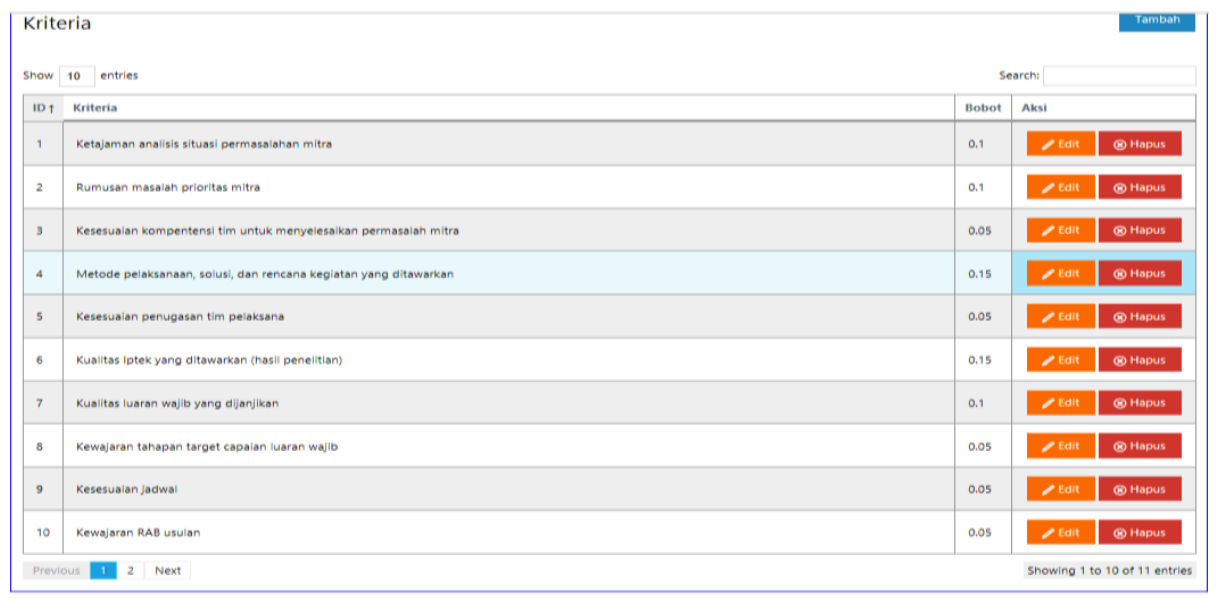

Gambar 2. Data Kriteria

Pada gambar 2 adalah data kriteria yang terdiri dari 11 kriteria yang digunakan untuk proses seleksi proposal pengabdian kepada masyarakat sesuai dengan bobot dari masing masing kriteria. Data kriteria diolah pada bagian unit penelitian dan pengabdian masyarakat.

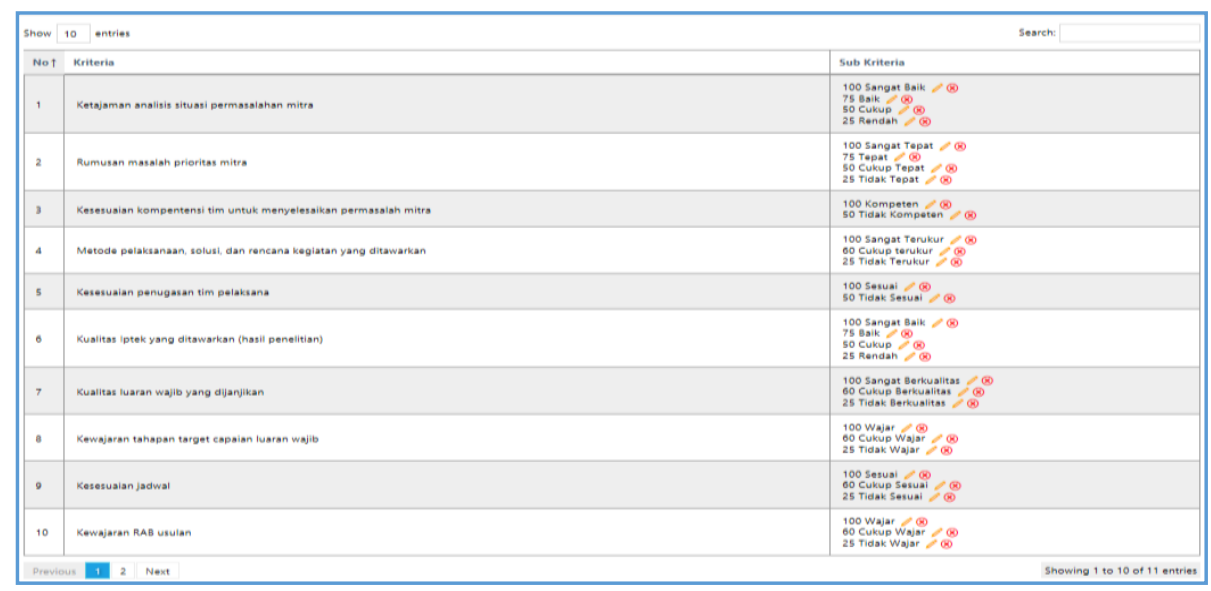

Gambar 3. Data Subkriteria

Pada gambar 3. Subkriteria merupakan bagian dari kriteria yang terdiri dari bobot subkriteria yang digunakan sebagai nilai untuk proses perangkingan seleksi proposal pengabdian kepada masyarakat sesuai dengan kriteria yang ada pada gambar2. Bobot subkriteria 
diperoleh berdasarkan nilai $\mathrm{C}_{\text {out }}{ }^{\mathrm{i}}$ yang dihitung berdasarkan persamaan ke-2 dari metode SMART.

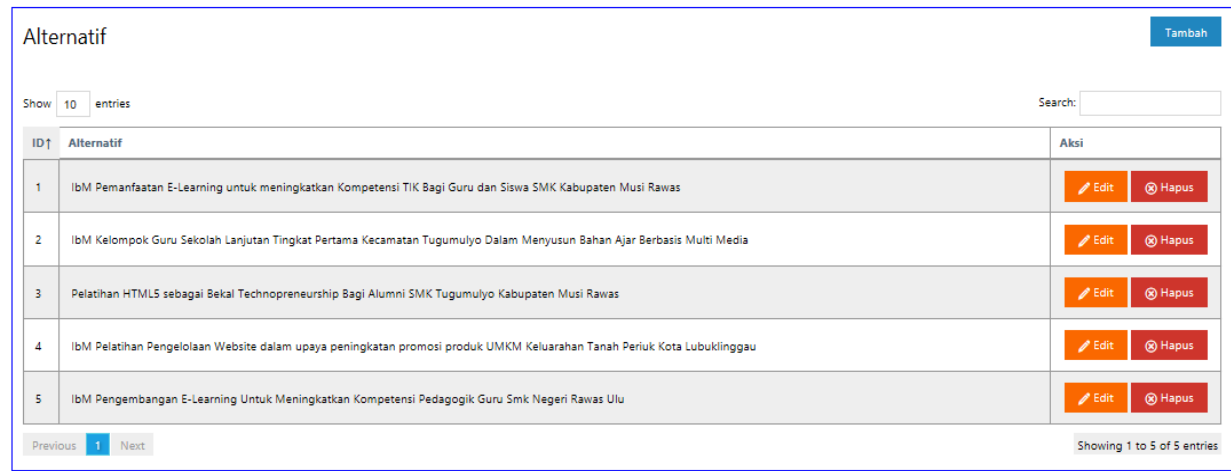

Gambar 4. Data Alternatif

Pada gambar 4. Menjelaskan data alternatif yang digunakan adalah data usulan proposal pengabdian masyarakat pada tahun 2017 untuk proses seleksi proposal pengabdian kepada masyarakat, dimana data alternatif dikelola bagian unit pengabdian masyarakat.

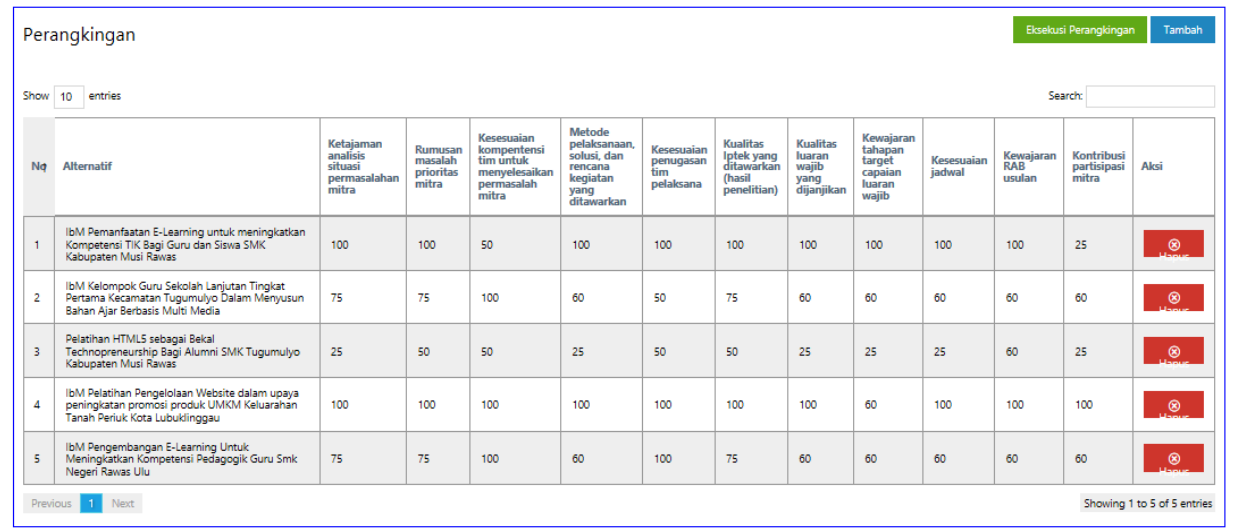

Gambar 5. Proses Perangkingan

Pada proses perangkingan pada gambar 5 diatas merupakan proses entri data bobot kriteria yang dilakukan pada sistem yang dibangun sesuai dengan hasil penilaian yang dilakukan oleh tim review proposal pengabdian masyarakat. Data tersebut digunakan sebagai dasar untuk dapat melakukan penilaian yang bertujuan untuk menghasilkan perangkingan sesuai dengan nilai rekomendasi.

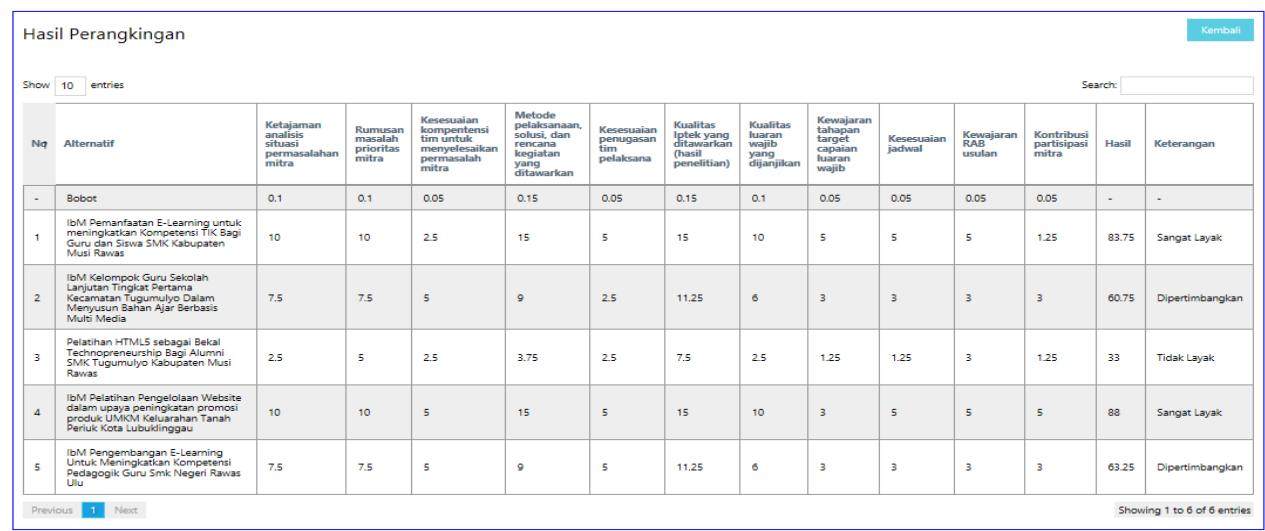

Gambar 6. Hasil Perangkingan

Pada gambar 6. Dari sistem yang dibangun dihasilkan perangkingan dengan nilai rekomendasi yang sama dengan menggunakan metode simple multi attribute rating technique 
yaitu pada alternatif $A_{1}$ dan $A_{4}$ dengan nilai rangking 83,75 dan 88 dengan rekomendasi sangat layak, sedangkan pada $A_{2}$ dan $A_{5}$ dengan nilai rangking 60,72 dan 63,25 dengan rekomendasi dipertimbangkan dan untuk $\mathrm{A}_{3}$ nilai rangking 33 dengan rekomendasi tidak layak.

\section{Kesimpulan}

Dari hasil pembahasan dapat disimpulkan bahwa Metode Simple Multi Attribut Rating Technique dapat melakukan proses perangkingan seleksi proposal pengabdian masyarakat dengan banyak kriteria. Adapun hasil analisa baik dari metode dan sistem yang dibangun diperoleh alternatif terbaik dari beberapa proposal pengabdian masyarakat yaitu pada $\mathrm{A}_{1}$ dan $\mathrm{A}_{4}$ direkomendasikan sangat layak untuk diterima, sedangkan pada $\mathrm{A}_{2}$ dan $\mathrm{A}_{5}$ direkomendasikan untuk dipertimbangkan dan untuk $\mathrm{A}_{3}$ direkomendasikan tidak layak. Adapun saran untuk kedepan dari penelitian ini perlu dilakukan kombinasi metode $A H P$ sebagai penentuan bobot kriteria yang tepat dan metode SMART digunakan untuk proses perangkingan. Sedangkan untuk sistem perlu dikembangkan pada proses seleksi penilaian pada semua skema pengabdian kepada masyarakat.

\section{Daftar Pustaka}

[1] D. K. Riset, Buku Panduan Pelaksanaan Penelitian dan Pengabdian kepada Masyarakat Edisi XII. 2018.

[2] Robi Yanto, "Sistem Pendukung Keputusan Prioritas Investasi dalam upaya Peningkatan Kualitas Perguruan Tinggi," J. Resti, vol. 1, no. 3, pp. 211-216, 2017.

[3] Y. Primadasa and H. Juliansa, "Penerapan Metode Vikor dalam Seleksi Penerimaan Bonus Pada Salesman Indihome," pp. 33-43.

[4] B. K. T.Rahayu, E. Nanik, "Metode Analytical Hierarchy Process Dalam Menentukan Pemilihan Desa Terbaik," vol. 1, no. 10, pp. 94-99, 2019.

[5] Faizal, F. Agus Setyaningsih, and M. Diponegoro, "Implementasi Sistem Pendukung Keputusan Dengan Metode SMART Untuk merangking Kemiskinan Dalam proses Penentuan Penerima Bantuan PKH," Coding J. Komput. dan Apl. Untan, vol. 05, no. 2, pp. 13-24, 2017.

[6] N. Sesnika, D. Andreswari, and R. Efendi, "Aplikasi Sistem Pendukung Keputusan Pemilihan Gedung Serba Guna Di Kota Bengkulu Dengan Menggunakan Metode Smart Berbasis Android," J. Rekursif, vol. 4, no. 1, pp. 30-44, 2016.

[7] Y. Purnamasari, T. H. Pudjiantoro, and D. Nursantika, "SISTEM PENILAIAN KINERJA DOSEN TELADAN MENGGUNAKAN METODE SIMPLE MULTY ATTRIBUTE RATING TECHNIQUE ( SMART ).," vol. 8, no. 1, pp. 16-23, 2017.

[8] C. Journal, R. Yanto, and S. Informasi, "Penerapan Metode Analytical Hierarchy Process dalam Upaya Peningkatan Kualitas Objek Wisata," vol. 4, no. 3, pp. 163-173, 2017.

[9] B. Hartanto, Sistem Informasi Manajemen Berbasis Komputer, First Edit. Jakarta: Rineka Cipta, 2013.

[10] E. Yulianti, D. Jurusan, T. Informatika, and F. T. Industri, "Jurnal Momentum ISSN : 1693-752X SISTEM PENDUKUNG KEPUTUSANPEMILIHAN MOBIL DENGAN METODA SIMPLE MULTY ATTRIBUTE RATING ( SMART ) Jurnal Momentum ISSN : 1693-752X," vol. 17, no. 1, 2015.

[11] M. Safrizal, "Sistem Pendukung Keputusan Pemilihan Karyawan Teladan dengan Metode SMART ( Simple Multi Attribute Rating Technique )," vol. 1, no. 2, pp. 25-29, 2015. 
